\title{
Internal Audit and Creative Accounting Practices in Ministries, Departments and Agencies (MDAs): An Empirical Analysis
}

\author{
Stanley Ogoun, Emmanuel Atagboro \\ Department of Accountancy, Management Sciences, Niger Delta University, Amassoma, Bayelsa State, Nigeria \\ Email: stanleyogoun@ndu.edu.ng, atagboroemmanuel@yahoo.com
}

How to cite this paper: Ogoun, S. and Atagboro, E. (2020) Internal Audit and Creative Accounting Practices in Ministries, Departments and Agencies (MDAs): An Empirical Analysis. Open Journal of Business and Management, 8, 552-568. https://doi.org/10.4236/ojbm.2020.82034

Received: January 7, 2020

Accepted: February 28, 2020

Published: March 2, 2020

Copyright $\odot 2020$ by author(s) and Scientific Research Publishing Inc. This work is licensed under the Creative Commons Attribution International License (CC BY 4.0).

http://creativecommons.org/licenses/by/4.0/

\begin{abstract}
The study interrogated the relationship between internal audit function and creative accounting practices in the public service domain in Nigeria using Ministries, Departments and Agencies (MDAs) as the focal group. The study is based on the continuous cases of fraud in the public service, evidenced by bogus financial reports inundating the Nigerian civil service domain that is anchored on agency and information theories and shaped via the survey approach, by gathering data from systematically sampled respondents of the internal audit unit of MDAs based in Bayelsa State. Using the SPSS tool to analyse the data collected via a structured questionnaire which observed that the internal audit function has a bearing on creative accounting practices in MDAs. Thus, this inferred that as the first line of defence against financial fraud in the internal control context, an efficient internal audit can certainly curb accounting information manipulations and this forms the basis for recommending that; provide enabling environment for the optimal functioning of the internal audit unit in all MDAs, imposition of appropriate sanctions on staffers of MDAs that compromise the common good for private interest as stewards of public resources, a stronger regulatory regime with adequate enforcement machinery for ensuring compliance with accounting and auditing standards should institutionalise in all MDAs in Nigeria, regular training of audit staff to apprehend current developments in accounting practice, as well as ensure the employment of qualified audit staff with the requisite skills and appropriate remuneration.
\end{abstract}

\section{Keywords}

Internal Audit, Creative Accounting, MDAs, Public Sector 


\section{Introduction}

The fraud menace has continued to be spotlighted both in the private and public sector domains. Beyond the 2001 Enron Corporation scandal that orchestrated debate about increased regulation and control of private-sector holdings, financial management in the public domain has also received a fair share of attention. One glaring fallout of the Enron debacle is the realisation that the much-espoused concept of the free market enterprise model has severe issues of self-regulation. The pursuit of profit and unbridled market expansion in private-sector driven economies comes at a cost, which if not mitigated portends catastrophic consequences for the national and global economy as witnessed in the 2008 financial crisis that rattled the global economy. While private-sector holdings are grappling with issues of fraud and creative accounting innovations, the public domain is also witnessing its demons of financial fraudulence.

Interestingly, all stakeholders agree that fraud in either domain has a critical debilitating effect on the overall systems' objective. In this light, there is a commonality of opinion that accountability, transparency and integrity must characterize all forms of human socio-economic group interactions and this arguably is well collocated within the framework of the fact that stewardship has become a cardinal aspect of the current models of social interactions within the globe. No single individual can form and at the same time, manage a standard firm, without deploying some form of delegated responsibility. Furthermore, it is practically impossible for nation-states to be administered by all citizens at the same time. This critical realisation forms the foundation for delegated responsibility and by extension, the act of stewardship.

As recognised in the existing literature, stewardship demands fiscal responsibility and accountability in all instances. However, various globally reported and unreported financial misconducts, have resulted in the refining of previously existing economic regulatory and reporting frameworks, as well as the enactment of new ones. As evidenced in the context for the preparation and presentation of financial statements of the IASB, the analysis of qualitative characteristics of accounting information is carried out around four (4) vectors: understandability, relevance, reliability and comparability [1].

One of the cardinal requirements for any sound accounting system is the institutionalisation of internal control. Premised on this is the centrality of internal audit in the internal control system. The essence of internal control is to ensure that the accounting system delivers on its satisfaction of stakeholder requirements for reliable financial information. It was and is still believed, to the extent that, a functional internal audit system assures the quality of financial reports and expected that the internal audit serves as financial quality assurance compliance tool. Nevertheless, the existence of internal audit has not foreclosed the prevalent rate of fraudulent financial transactions, neither reporting. Very significant in this regard, is the fact that public revenue and expenditure profile of the MDAs are often not subjected to external audit. The external audit of MDAs 
in Nigeria is handled by the office of the Auditor General, which relies heavily on the optimality of the internal audit function and expects that all financial transactions in MDAs pass through internal audit vetting. Meanwhile, the entire public inundated financial landscape with news of dysfunctional behaviour leading the doubts about the role of internal audit in the whole of the fraudulent financial transaction chain. It is in this regard we investigate the role of internal audit in the manipulation of the number-games in the public financial domain.

\section{Review of Related Literature}

\subsection{The Concept of Internal Audit and Its Role}

An audit is to attest to the accuracy of financial statements or situation because the primary purpose of a review is to examine and express an opinion on the result and state of affairs of an enterprise as much as its financial operations and records can reveal. This expression of opinion leads credence to attached financial statement, so that the user is free to rely on them (financial statement); since independent expert has certified their accuracy. An audit is seen as an independent examination of and expression of opinion on the financial report of an organisation, by an appointed auditor in pursuance of that appointment and compliance with any relevant statutory obligation. The American Committee on Basic Auditing Concepts defined auditing as a systematic process of objectively obtaining and evaluating evidence regarding proclamations about economic activities and events to ascertain the degree of correspondent between those affirmations and established criteria and communicating the results to the interested users.

To [2], auditing is the process of providing free and fair view about the books of accounts, vouchers, balance sheet and ledgers of an enterprise. Auditing is an essential field of study for most societies. Audit profession provides services, such as assurance, attestation, review of historical financial statement and other attestation services. Meanwhile, in 1999, [3] has defined internal auditing as an independent, unbiased assurance and consulting activity aimed to add value and improve an organisation's operations. It helps an organisation achieve its objectives by bringing a systematic, disciplined methodology to appraise and develop the efficiency of risk organisation, control, and governance procedures. Internal audit is an appraisal (evaluation) activity established within a company as a service, and its functions include; scrutinising, appraising and checking the adequacy and effectiveness of the accounting and internal control systems. Thus, an internal audit is the internal mechanism for financial quality assurance compliance.

The central role of internal auditing is to add value to the organisation by performing assurance and consulting undertakings. They need to be operational, tactical, strategic and improve operations. However, the clarification of this role is broad. Primary duties of assistance with risk management, control, and governance processes will add a different value to the enterprise. In reality, the role 
of internal audit [4] depends on the specific needs of organisations and the sector they are operating. In this regard, [5] had earlier listed observed that: for organisations in the scandal-ridden industry, value-adding auditing service will be compliance reviews; for organisations in quickly growing sectors, value-adding will be consulting counsel on programs and projects; for organisations in developing countries, it may be building controls and preventing fraud or corruption; for global organisations, it may be management of the risks and logistics of coordinating information with the head office and so on.

[6] provides another categorisation of internal audit's role based on the type of organisation (public or corporate sector) rather than the organisation's environment as Pickett suggested it. For the public sector, internal audit's role focused on the efficient and effective expenditure of public money. In the corporate setting, internal audit's position is measured by and focused on its ability to satisfy stakeholders and ensure profit. For further aspects of the place of internal audit, see ([4]-[11]). Also, for the history and attributes of internal audit see ([4] [12] [13] [14]). The literature clear captures the centrality of the role of internal control (the position of internal audit) as the first line of defence against financial fraud, which underscores its imperative. Internal audit plays a vital role in any enterprise. Internal audit sees or evaluates things like an Eye. So a well-designed internal audit structure has the capacity for foreclosing the practice of creative accounting.

\subsection{The Creative Accounting Domain}

The basic idea of innovative accounting is finding the so-called loopholes in law and accounting standards to enhance financial statement and present the business in a positive light. Income smoothing can have a positive impact on trade Business, but only when it is applied in a positive sense, and is used to achieve the overall objective of the organisation. However, it often happens that companies' cross boundaries of simplicity and abuse such practice, which can lead to fatal consequences. One thing is sure; creative accounting most often harms financial reporting [15].

[16] pronounced that firms generally prefer to report a steady trend of growth in return rather than to show volatile returns with a series of dramatic rises and falls and the achievement is by making extra significant provisions for liabilities and against assets values in good years so that the regulations can be subsequently abridged, thereby improving reported returns, in bad years. Advocates of this methodology argue that it is a measure against the short-termism of judging an investment based on the yield achieved in the immediately following years. [17] investigated the problem concerning both managers and shareholders and argued that the internal audit is essential, an organisation where the internal audit regarded as the critical element in the application of accounting system this will in turn help in reducing creative accounting.

Although several researchers have studied and published papers in creative 
accounting, it does not yet have any universally accepted conceptual definition. [18] argues that the difficulty in accepting a unified description of the concept of creative accounting lies in the existence of different insights and opinions regarding the operationalisation of the concept. There are various strands of opinion on creative accounting, but they boil down to the same idea. Creative accounting is defined as accounting manipulation to take advantage of gaps in accounting rules and measurement and disclosure practices [19]. Most firms in the globe are fiddling with their reported profit figures for various reasons. [1] noted that every set of published accounts, is based on books which may have been gently cooked or changed in other to protect the guilty; that usage of many terms are to label the practices of changing the facts in accounting, e.g. window dressing, cooking the books, as a result of this the internal audit objective perspective, and skills can help or assist in preventing accounting manipulation. In the same vein, most financial reports from the public sphere have doctored to meet citizens' expectation.

Creative accounting, according to [20], is the manipulation of financial numbers or transfer of figures. The concept of creative accounting became popular about two (2) decades ago. They are manipulating numbers to get favourable accounting impression. The positive side of the earnings management refers to the request of the best choices and the vital goal being that the information in the financial statement reflects the true and fair view of the financial position [21]. [22] noted that the manipulation of account might affect the business of the organisation. They suggested that every organisation should fill the loophole by having a good or quality internal audit system that will regulate and monitor policies and procedures in the organisation. The widespread corruption in the society and the failure of organisations in every part of the world have again increased the need for accounting professionals to adhere strictly to the codes of professional practice [23].

Manipulations in financial reporting give only short term advantage. [24] concluded that creative accounting is a weapon used in a critical situation of a firm. The paper finds that there is no satisfactory solution to the problem of creative accounting. But by having a good and quality internal audit, we can control the practices to some extent. Creative accounting is termed a synonym for deceptive accounting. According to [25], ethical behaviour of a person in accounting depends on ethical understanding, verdict, incentive and qualities. According to [26], the ambition of making figures more appealing or the opposite as the circumstances demand is as old as five centuries. Academically, income smoothing is the process of transforming financial accounting numbers to the figures that are being desired by them (prepares) from what they represent values while ignoring accounting rulers [27]. Creative accounting is also known as "Earnings management" or aggressive accounting or it refers to accounting practices that may not follow the letter of accounting standard practices or within the accounting regulatory framework. Earnings management is fraud 
when practised out of the regulatory framework, and if proper checks and balances or internal investigation not carried out within the organisation, there will be misinformation to stakeholders.

Furthermore, creative accounting involves the adoption of a legal and optional opinion between different accounting methods to address a specific case in situations where the relevant accounting standards or principles do not refer to a direct way of solving a problem or do not suggest alternative methods [28] [29] describes innovative accounting as an accounting exercise that may or may not adhere to accounting philosophies and standards, but deviates from what those principals and standards intended to achieve, in other to present the desired business image. On their part, [30] argue that creative accounting indicates when accounts are based on what managers want, rather than as they should be, by not objectively applying accounting rules. The prevalence of the number games driven by the fact that there are many users of financial statement who are not aware of creative accounting and thus management gets chance to mould the books in the way they want.

Furthermore, the existing literature has identified creative accounting stimulants (what [15], regards as sources of inspiration) to include; flexibility in accounting regulation, lack of control, use of management discretionary position, timing of the transaction, the use of artificial transactions, big-bath accounting, and using cookie jar reserves. These constitute the foundation for the various typologies of creative accounting to include; manipulation of off-balance-sheet financing items, variations in accounting strategies and depreciation techniques, manipulation of other income and expense items, change in value of money, overestimation of revenues by recording fictitious sales revenue, manipulation of receivables write off and manipulation of accruals.

For the motives (which range from tax, managerial compensation, capital market pressure, share prices, insider dealing, to meeting contractual obligations) of responding positively to the creative accounting stimulants see the works of ([15] [22] [31]-[40]). While for way and means of mitigating innovative adverse accounting, in [41].

From the above, it is clear that creative accounting is an exercise that the management deliberately uses to prepare and report the company profits to reflect the wishes and interest of the company rather than to reflect the company's real economic or financial performance. Also, it entails the deployment of accounting tools or taking advantage of loopholes to manipulate public financial reports to meet citizens' expectation.

\subsection{Theoretical Premise and Hypothesis Development}

[42] noted that there is no universally or unanimously accepted theory for studying creative accounting which is because of the varying positive values and negative values of creative accounting. Hence, this study reviews relevant approaches often used in the discussion of creative accounting and takes position. 


\subsubsection{Agency Theory}

Agency theory is a contractual relationship between two or more parties where one (who is the principal) engages another person to perform a service on their behalf which involves delegating decision making authority to the person engaged herein referred to as the agent. This theory assumes that both the principal and the agent are utility maximisers with different interest, and that arising from information asymmetry, the agent will not always act in the best interests of the principal. The principal can limit the divergence of interest by establishing appropriate incentives for the agent and by incurring costs termed agency costs. The premise of the theory by [43] finds applicability in the public domain. It is because those who manage public resources are supposedly doing so in the interest of the citizens who are their principal.

\subsubsection{Information Theory}

Information perspective is as an essential aspect underpinning the study of creative accounting practices. [44] argued that information asymmetry has the potential to explain the numerous encouragements captured on the financial market to manipulate accounting number and further to assess the consequence of such behaviour. The study also noted that information asymmetry is an integral part of economic theory. Directors may choose to exploit their privileged position for private gains by managing financial reporting disclosure in their favour. The information perception assumes that accounting disclosures have information content that possesses value to stakeholders in providing useful signals. It may be difficult or impossible for distinct stakeholders to distinguish the fact and the effect of accounting manipulation, because of insufficient personal skill, indifference or an unwillingness to engage in detailed analysis. Therefore, these two theoretical espousals guided the investigation.

\subsection{Prior Works}

[4] investigated whether companies use innovative accounting techniques to meet the analysts' projections and exceed the previous year's earnings and whether the market rewards or disciplines such as manipulations. The study shows that all the corporations that have managed to beat the targets have used creative accounting methods to increase earnings artificially and have been rewarded by the market for doing so. In contrast, companies that have managed revenues to shrink them, so that they barely meet the set goals, were not rewarded.

[13] inquired on the importance of internal audit and internal control in an organisation. Based on the results of this research, it is easy to conclude that internal control influences operations on an everyday basis. Properly developed internal control can positively influence business operations, risk management, and decision making on all levels of the organisation.

[29] examined India's Enron, Satyam Computers Creative Accounting scandal and underlying reasons for the prevalence of frauds in the banking industry. $\mathrm{He}$ suggested the increasing rate of white-collar crimes demands stiff penalties, ex- 
emplary punishments, and effective enforcement of the law with the right spirit.

[45] researched the effect of the internal audit and firm performance, and they concluded that the internal audit department is essential inside a firm where the internal audit is regarded as the vital element in the application of accounting systems and helps in evaluating the work of the department. This study reviews internal audit studies and found that only a few studies investigated the relationship between internal audit, firm performance and earning management. Last but not least, inconsistent to the value of the integration between accounting-based measure and market-based measure together to enhance the performance of firms to provide a clearer picture to investors, future studies should look into how this integration should take place.

On his part, [46] studied the impact of creative accounting techniques on the reliability of financial reporting from auditors and academics point of view. The study found out that innovative accounting techniques have positive and negative effects. This study only considers the adverse effects of creative accounting techniques on the reliability of financial reporting. The study concludes that the statutory auditor can play a useful role in reducing the impact of innovative accounting techniques on security (reliability of financial reporting. The study found that active corporate governance principles control the practices of creative accounting by using independent non-executive directors.

In an earlier study, [47] examined creative accounting as an auditor's role in detecting financial fraud. They opined that an auditor should bear in mind the following points: Creative accounting practices may often be tantamount to misleading the users of financial statements, and auditors should always be alert to the possibility that they amount to actual fraud; Creative accounting practices that may indicate the presence of fraud are more worrying than accounting errors; Auditors need to increase their vigilance in conducting audits, especially if the indicators of creativity raise suspicions that the purpose may be to fraudulently manipulate the accounts; Detecting creative accounting practices is not an easy task, but auditors should not pass on their responsibilities to others. If the task of detecting creative accounting using standard audit procedures is too tricky, auditors should consider seeking other methods to identify such practices. The study observed that understanding the issue of creative accounting will help auditors to ensure a high quality of financial reporting and to maximise returns to stakeholder.

[48] surveyed the existence of a gap between accounting and auditing perceptions of creative accounting, and possible solutions to regulate such practices in Bangladesh. The study concludes that there is no reason to punish either auditors or accountants for applying creative accounting. Management Accountants are only company personnel that follow management instructions. Meaning, if management requires that financial reports are to be prepared and presented in a certain way, internal accountants will predominantly be concerned about keeping their jobs and will follow the guidelines accordingly. Therefore, man- 
agement should be held criminally liable for the abuse of creative accounting.

Similarly, [49] conducted a study on fraudulent financial reporting in Malaysia, focusing on the innovative accounting tactics engaged and the drives for such arrangements. The research outcomes exhibited that the most commonly used modus operandi of inspired accounting was the overestimation of revenues through recognition of fictitious revenues from product sales to bogus customers. One of the key recommendations of the research is that auditors should review the effectiveness of their analytical and material processes since there is a significant number of cases of innovative or dishonest accounting that remain undetected by the audit process.

[50] explored the influence of creative accounting on firm value in Nigeria, and the findings of the article revealed that it could positively affect firms' value. Another study, which also focused on Nigeria, is by [51], using survey method, to investigate the practice of creative accounting, its nature, procedures, and prevention, concluded that one of the best ways to prevent the practice of earnings management is to enforce both preventive as well as healthy enough punitive measures on those that engage in the practice. Similarly, [52] undertook to investigate the opinions of experienced staff of commercial banks on creative accounting practices in Nigeria. Based on their study, they recommended that income smoothing should reflect as a severe crime and as such, accounting bodies, law courts and other regulatory authorities need to adopt strict measures to stop the practice.

Also, [53] undertook empirical analysis by conducting a study in some selected private sector undertakings in Kolkota, Bhubaneswar and Cuttack. He used questionnaire and Likert scale method and concluded that window dressing practices are prevalent in the majority of corporations and external auditors encourage such practices for their interest. Furthermore, [54], in their empirical study, collected data through a structured questionnaire from the industrial sector of Pakistan. The study concluded that an enterprise is involved in frauds or scandals because of several factors like unethical behaviours, agency problem and non-professional attitude.

The above-reviewed studies are focusing on different dimensions of creative accounting, particularly in the private sector. So far, no detailed research study has been undertaken to investigate the window dressing domain in the public sector in a developing nation like Nigeria and linked to the absence of formal financial reporting within the public domain. This gap is what the study seeks to fill and contribute to the body of knowledge. Against this backdrop, the study hypothesises that:

$\mathrm{Ho}_{1}$ : Internal audit has no significant bearing on creative accounting practices in MDAs in the Nigerian public domain.

\section{Methodology}

The research design used was the survey type. Internal audit departments of 
MDAs in Bayelsa State constitute the population of the study. The paper used a stratified probabilistic sampling technique in selecting respondents from the sample frame and responses obtained from 50 staffers out of 60 of the internal audit departments of MDAs in Bayelsa State (that is, ten out of the 60 questionnaire were not retrieved from the respondents, representing $16.6 \%$ of the total instruments administered). This study employed the primary mode of data collection and the questionnaires pretested to ensure relevance. The questionnaire is designed to interrogate functions and impact of internal audit on creative accounting practices in MDAs of the target population. And applied Cronbach Alpha reliability test to determine the internal consistency of the instrument and a reliability index of 0.73 on average obtained for the sections and is being within the range recommended by Cronbach as a reliable instrument.

\section{Model Specification:}

To test the hypotheses of the study and to examine the relationship between internal audit and creative accounting practices in organisations in Nigeria, the highlight of the functional relationship (model) is:

$$
C A P=f(\text { Internal Audit and Challenges of Internal audit })
$$

Econometrically, the above functional relationship is as expressed:

$$
C A P_{i t}=\alpha_{i t}+\beta_{1} I A U D_{i t}+\varepsilon_{i t}
$$

The variables of the above model are defined as follows:

$C A P_{i t}=$ Creative Accounting Practices in time/year $t$,

$I A U D_{i t}=$ Bearing of Internal Audit in time/year $t$,

$\varepsilon_{i t}=$ Error term,

$\alpha_{i t}=$ Constant/intercept.

The article used SPSS version 26 in analysing the data obtained via the questionnaire. The measures used to describe the data set are measures of central tendency and measures of variability or dispersion. Measures of central tendency included the meanwhile a measure of variability consists of the standard deviation (or variance); the minimum and maximum variables and data presented in forms of tables. Inferential statistics used was Pearson Correlation and Analysis of Variance (ANOVA) to test the hypothesis to determine the nature and strength of the nexus between internal audit and creative accounting practices in MDAs in Nigeria.

\section{Results and Discussion of Findings}

Table 1 highlights questions on challenges faced by internal auditors in optimally practicing internal audit in MDAs and the State's internal audit unit.

Table 1 presents the questions on what are the challenges affecting internal audit in an organisation. The result showed that all the eleven (11) items on internal audit scored above 2.50 cut-off point of the mean and it suggests that the eleven (11) questions are good indicators in assessing the challenges affecting internal audit. On the overall, the grand mean of 3.2618, which is above the 
cut-off point of mean is an indication that the organisation considers the challenges affecting internal audit as significant or accurate.

Table 2 presents how Internal Audit can be used to curb Creative Accounting among employees of the MDAs. The result showed that all eleven (11) items on Internal Audit scored above 2.50 cut-off point of the mean and this implies that the eleven (11) perceptions are good indicators in assessing how Internal Audit can curb Creative Accounting. The grand mean of 4.1855, which is above the

Table 1. Descriptive statistics showing responses on challenges affecting internal audit.

\begin{tabular}{|c|c|c|c|c|c|}
\hline & $\mathbf{N}$ & Min & $\operatorname{Max}$ & Mean & Std. Deviation \\
\hline Lack of independence & 50 & 1.00 & 5.00 & 4.1200 & 1.08119 \\
\hline Self-interest threats & 50 & 1.00 & 5.00 & 3.1600 & 1.16689 \\
\hline Familiarity threats & 50 & 2.00 & 5.00 & 3.7200 & 0.78350 \\
\hline Intimidation threats & 50 & 1.00 & 5.00 & 3.3600 & 1.17387 \\
\hline Advocacy threats & 50 & 1.00 & 5.00 & 3.3200 & 0.97813 \\
\hline Conflict of interest between workers & 50 & 1.00 & 5.00 & 2.9200 & 0.98644 \\
\hline Ignorance or disregard of relevant legislation, rules, regulation & 50 & 1.00 & 5.00 & 2.7200 & 1.16128 \\
\hline Lack of internal controls & 50 & 2.00 & 5.00 & 3.4000 & 1.17803 \\
\hline False and misleading entries in account or records & 50 & 1.00 & 5.00 & 3.2400 & 1.15281 \\
\hline $\begin{array}{l}\text { lack of technical expertise amongst regulatory agencies to quickly detect and isolate } \\
\text { incidence cases }\end{array}$ & 50 & 1.00 & 5.00 & 2.9600 & 1.19455 \\
\hline Valid N (listwise) & 50 & & & & \\
\hline GRAND MEAN/STD.DEV & & & & 3.2618 & 1.09557 \\
\hline
\end{tabular}

Field survey 2019.

Table 2. Descriptive statistics showing responses on how internal audit can curb creative accounting practices.

\begin{tabular}{|c|c|c|c|c|c|}
\hline & $\mathbf{N}$ & Min & $\operatorname{Max}$ & Mean & Std. Deviation \\
\hline The independence of the auditor & 50 & 1.00 & 5.00 & 4.4800 & 0.95276 \\
\hline The internal auditor has been free from all forms of threats that will lead to audit risk & 50 & 1.00 & 5.00 & 4.4000 & 0.98974 \\
\hline The internal auditor paying much attention to high-risk areas & 50 & 2.00 & 5.00 & 4.4000 & 0.75593 \\
\hline The internal auditor exercising due care in performing his work & 50 & 2.00 & 8.00 & 4.8400 & 1.68256 \\
\hline Monitoring of the daily activities of the workers & 50 & 1.00 & 5.00 & 3.3200 & 1.09619 \\
\hline The integrity of the internal auditor & 50 & 1.00 & 5.00 & 4.3200 & 0.93547 \\
\hline Adhering to the code of confidentiality & 50 & 2.00 & 5.00 & 3.7600 & 1.07968 \\
\hline Constructive working relationship with mutual understanding & 50 & 1.00 & 5.00 & 3.6400 & 1.02539 \\
\hline Development and maintenance of Internal Audit standards & 50 & 2.00 & 5.00 & 4.2400 & 0.87037 \\
\hline Diligence of an internal auditor & 50 & 3.00 & 5.00 & 4.2000 & 0.69985 \\
\hline Professional proficiency & 50 & 3.00 & 5.00 & 4.4400 & 0.64397 \\
\hline GRAND MEAN/STD.DEV & & & & 4.1855 & 0.97563 \\
\hline
\end{tabular}

Field survey 2019. 
cutoff point of the average shows that there is a connection between employees of Bayelsa state Internal Audit considers Internal Audit (techniques) and creative accounting. This implies that internal audit has a strong effect on reducing or curbing negative creative accounting practices in MDAs in Nigeria.

There is indeed a strong positive relationship between internal audit and creative accounting with the correlation coefficient, $r=0.936$ and $p=1.00$. Since $r<$ 1.00 , this implies that there is a significant relationship between internal audit and creative accounting. Meaning that inspired accounting practice is significantly affected by internal audit function in MDAs in the public service domain.

Presented in Table 3 is the relationship between internal audit and creative accounting practices in Ministries, Departments and Agencies. The results showed that there is a strong positive relationship between internal audit and creative accounting with the correlation coefficient, $r=0.936$ and $p=1.00$. Since $\mathrm{r}<1.00$, which means that there is a significant relationship between internal audit and creative accounting.

Tables 4(a)-(c) show the regression results for internal audit and creative accounting. The R-Squared is 0.876 , suggesting that the independent variable explains about $87.6 \%$ of the systematic variations in the dependent variable for

Table 3. Relationship between internal audit and creative accounting.

\begin{tabular}{cccc}
\hline & & Creative Account & Internal Audit \\
\hline \multirow{2}{*}{ Pearson Correlation } & Creative Accounting & 1.000 & 0.936 \\
& Internal Audit & 0.936 & 1.000 \\
& Creative Accounting & $\cdot$ & 0.000 \\
Sig. (1-tailed) & Internal Audit & 0.000 & $\cdot$ \\
& Creative Accounting & 50 & 50 \\
$\mathrm{~N}$ & Internal Audit & 50 & 50 \\
\hline
\end{tabular}

${ }^{*}$ Correlation significant at 1.0 ( 1 tailed).

Table 4. (a) Model summary ; (b) ANOVA ${ }^{\mathrm{b}}$; (c) Coefficients ${ }^{\mathrm{c}}$.

(a)

\begin{tabular}{ccccccccccc}
\hline Model & $\mathbf{R}$ & R Square & $\begin{array}{c}\text { Adjusted } \mathbf{R} \\
\text { Square }\end{array}$ & $\begin{array}{c}\text { The standard error } \\
\text { of the estimate }\end{array}$ & $\begin{array}{c}\text { R Square } \\
\text { Change }\end{array}$ & F Change & df1 & Change Statistics \\
\hline 1 & $0.936^{\mathrm{a}}$ & 0.876 & 0.873 & 3.34888 & 0.876 & 338.624 & 1 & 48 & 0.000 \\
\hline
\end{tabular}

apredictors: (Constant), Internal Audit.

(b)

\begin{tabular}{ccccccc}
\hline & Model & Sum of Squares & Df & Mean Square & F & Sig. \\
\hline \multirow{3}{*}{1} & Regression & 3797.679 & 1 & 3797.679 & 338.624 & $0.000^{\mathrm{b}}$ \\
& Residual & 538.321 & 48 & 11.215 & & \\
& Total & 4336.000 & 49 & & & \\
\hline
\end{tabular}

bDependent Variable: Creative Accounting; Predictors: (Constant), Internal Audit. 
(c)

\begin{tabular}{|c|c|c|c|c|c|c|c|c|}
\hline & \multirow{2}{*}{ Model } & \multicolumn{2}{|c|}{ Unstandardized Coefficients } & \multirow{2}{*}{$\begin{array}{c}\begin{array}{c}\text { Standardized } \\
\text { Coefficients }\end{array} \\
\text { Beta }\end{array}$} & \multirow{2}{*}{$\mathrm{T}$} & \multirow{2}{*}{ Sig. } & \multicolumn{2}{|c|}{$95.0 \%$ Confidence Interval for B } \\
\hline & & B & Std. Error & & & & Lower Bound & Upper Bound \\
\hline \multirow{2}{*}{1} & (Constant) & -13.407 & 2.491 & & -5.382 & 0.000 & -18.417 & -8.398 \\
\hline & Internal Audit & 0.978 & 0.053 & 0.936 & 18.402 & 0.000 & 0.871 & 1.084 \\
\hline
\end{tabular}

'Dependent Variable: Creative Accounting.

the sampled MDAs. The f-ratio is 338.624 , indicating that internal audit significantly affects creative accounting practices in the public service domain.

\section{Conclusions and Recommendations}

From the result of the data analysed and the results of the tests, it thus inferred that the internal audit function affects the level of creative accounting practices in MDAs. This observation mirrors similar conclusions on the centrality of internal audit as financial quality assurance and control mechanism, as well as being a major plank of the internal control framework. The implication of this is not far-fetched, as evidence shows that all MDAs have internal audit departments that vet all financial transactions in the public domain. By implication, no operation is concluded without audit input, thus signifying that an efficient internal audit unit would undoubtedly act as the first line of deterrence against financial misconduct.

The study recommends the provision of an enabling environment for the optimal functioning of the internal audit unit in all MDAs (that is, audit independence and confidentiality; free from threats such as self-interest, familiarity, intimidation and advocacy that will lead to audit risk; strong internal control system, and utmost cooperation between the agents and other stakeholders of the organisations) and the appropriate imposition sanctions on staffers of MDAs that compromise the common good for private interest as stewards of public resources. Also, a stronger regulatory regime with effective enforcement mechanisms for ensuring compliance with accounting and auditing standards should institutionalise in all MDAs in Nigeria to curb the menace of false and fictitious financial reports presented in any instance. Finally, there should be regular training of audit staff to apprehend current developments in accounting practice, as well as ensure the employment of qualified audit staff with the requisite skills and appropriate remuneration.

Due to the limitations faced by the researchers in carrying out this study, it is suggested that an indebt investigation should be carried out on this same topic (internal audit and creative accounting practices) in other parts of the country and also further research should be carried out on the dynamics of internal audit in curbing creative accounting practices.

\section{Conflicts of Interest}

The authors declare no conflicts of interest regarding the publication of this paper. 


\section{References}

[1] Laura, M.P. and Ileana, A. (2013) Detecting Creative Accounting Practices and the Impact on the Quality of Information Presented in Financial Statements. Journal of Knowledge Management, Economics and Information Technology, 3, 1-13.

[2] Arens, A., Randal, J. and Mark, S.B. (2015) Auditing and Assurance Services: An Integrated Approach.

[3] Institute of Internal Auditors (IIA) (2017) Corporate Governance. The Institute of Internal Auditors Homepage. https://Na.theiia.org

[4] Reding, K., Sobel, P., Anderson, U., Head, M., Ramamoorti, S., Salamasick, M. and Riddle, C. (2013) Internal Auditing. Institute of Internal Auditors, Research Foundation Altomonte, Springs, FL.

[5] Pickett, K. (2010) The Spirit Level: Why Equality Is Better for Everyone. Penguin, London, 347.

[6] Pitt, M.M. (2014) Research on Economic Development and Population Studies. Brown University, Providence, RI.

[7] Jovanovi, D. (2011) Empirical Research on the Internal Audit Position of Companies in Serbia. Economic Annals, 56, 123-141. https://doi.org/10.2298/EKA1191123L

[8] Russell, J. (2013) The ASQ Auditing Handbook. ASQ Quality Press, Milwaukee, WI.

[9] Yadav, B. (2013) Creative Accounting: A Literature Review. The SIJ Transactions on Industrial, Financial and Business Management, 3, 38-55.

[10] Ezeani, E. (2010) Effect of Creative Accounting on Stakeholders Wealth: A Case Study of 5 Companies Quoted in the Nigerian Stock Exchange. Project Regards, $1-67$.

[11] Ohja, B. (2012) Importance of Internal Audit and Internal Control in Organisation: Case Study. ARCADA, 1-57.

[12] Ramamoorti, S. (2011) The Corporate Ethics Audit: To Protect and Prevent Management Fraud, Internal Auditors Must Have a Sound Understanding of Human Behaviour. Accounting Faculty Publication, 95.

[13] Olga, S. (2017) Making Education Work: School Autonomy and Performance. East European Quarterly, 45, 27-56.

[14] Abdulrasheed, O. (2016) System of Education in Nigeria: Nomadic Education Perspective. LAP LAMBERT Academic Publishing, New York, 1-33.

[15] Ivani, K. and Ivo, M. (2019) Interdisciplinary Seminars as an Instruement for Articulation of Knowledge: An Experience Report. Revista Electronia Educacao, 13, 1-8. https://doi.org/10.14244/198271992532

[16] Ruland, R.G. (1984) Duty, Obligation and Responsibility in Accounting Policymaking. Journal of Accounting and Public Policy, 3, 223-237.

https://doi.org/10.1016/0278-4254(84)90018-8

[17] Revinse, L. (1991) The Selective Financial Misrepresentation Hypothesis. Accounting Horizons, 12, 16-27.

[18] Leuz, C. (2013) Earning Management and Investor Protection: An International Comparison. Journal of Financial Economics, 69, 505-527.

https://doi.org/10.1016/S0304-405X(03)00121-1

[19] Hussein, H.N. (2015) A Review of Creative Accounting Practices and Its Area, Technique and Ways of Prevention. International Journal of Science and Research, 4, 1377-1381. 
[20] Barnea, A., Ronen, J. and Sadan, S. (2011) Classificatory Smoothing of Income with Extraordinary Items. The Accounting Review, 51, 110-122.

[21] Victoria, F. (2014) An Empirical Study on the Impact of Creative Accounting Policies on the Performance of Listed Romanian Companies. Valerian Journal of Economic Studies, 5, 41-48.

[22] Effiok, S.O. and Eton, O.E. (2012) Creative Accounting and Managerial Decision on Selected Financial Institutions in Nigeria. International Journal of Business, Research and Management, 3, 35-47. https://doi.org/10.5430/ijfr.v3n4p116

[23] Ogbonna, G.N. and Appah, E. (2012) The Effect of Ethical Accounting Standards on the Quality of Financial Reports of Banks in Nigeria. International Journal of Business Behaviour Sciences Research, 2, 1-10.

[24] Shah, A.K. (2011) Creative Accounting: A Tool to Help Companies in a Crisis or a Practice to Land Them into Crises. In: International Conference on Business and Economics Research, IACSIT Press, Singapore.

[25] Usurelu, V.I., Danaila, A.E., Marin, M. and Daniela, L. (2010) Accounting Ethics: Responsibility vs Creativity.

[26] Balaciu, D., Bogdan, V. and Vladu, A.B. (2009) A Brief Review of Creative Accounting Literature and Its Consequences in Practice. Annales Universitatis Apulensis Series Oeconomica, 1, 175-187.

[27] Naser, K. (1993) Creative Financial Accounting: Its Nature and Use. Prentice-Hall, Hemel Hempstead.

[28] Hołda, A. and Staszel, A. (2016) Definition, Perception and Functioning of Creative Accounting in the Theory and Practice of Different Languages, Countries and Parts of the World.

[29] Bhasin, M.L. (2016) Survey of Creative Accounting Practices: An Empirical Study. Wulfenite Journal, 23, 143-162.

[30] Essien, E.A. and Ntiedo, J.U. (2018) The Influence of Creative Accounting on the Reliability of Accounting Reports. Journal of Financial Reporting and Accounting, 16, 292-310. https://doi.org/10.1108/JFRA-08-2016-0064

[31] Beatty, A. (2016) Earnings Management to Avoid Earnings Declines across Publicly and Privately Held Banks. The Accounting Review, 77, 547-570. https://doi.org/10.2308/accr.2002.77.3.547

[32] Bergstresser, D. and Phillppon, T. (2016) CEO Incentives and Earnings Management. Journal of Financial Economics, 80, 511-529. https://doi.org/10.1016/j.jfineco.2004.10.011

[33] Bewaji, W. (2012) Insider Trading in Developing Jurisdictions. Routledge, New York. https://doi.org/10.4324/9780203115497

[34] Cotleț, B.N., Nagy, C.M., Megan, O. and Cotleț, D.U. (2012) Creative Techniques for Modelling Performance Reported in Financial Statements. Anale. Seria Stiinte Economice. Timisoara, 18, 406-410.

[35] DeAngelo, H. (2014) Accounting Choice in Troubled Companies. Journal of Accounting and Economics, 17, 113-143. https://doi.org/10.1016/0165-4101(94)90007-8

[36] John, H. (2018) Influence of Creative Accounting Practices on Tax Evasion among Small and Medium Enterprises in Nakuru, Kenya. International Journal of Business Management and Processes, 4, 127-135.

[37] Muchina, S.W., Namusonge, G.S. and Sakwa, M. (2015) Effect of Dividend on Share Price Volatility in Frontier Exchanges: Kenya's Perspective. Research Journal of Fi- 
nance and Accounting, 6, 110-121.

[38] Mulford, C.W. and Comiskey, E.M. (2011) The Financial Numbers Game: Detecting Creative Accounting Practices. John Wiley and Sons, New York.

[39] Ramadan, I.Z. (2015) Earnings Quality Determinants of the Jordanian Manufacturing Listed Companies. International Journal of Economics and Finance, 7, 140-146. https://doi.org/10.5539/ijef.v7n5p140

[40] Petroni, K.R. and Yanyan, I.W. (2010) CFOs and CEOs: Who Have Most Influence on Earnings Management. Journal of Financial Economics, 96, 513-526.

https://doi.org/10.1016/j.jfineco.2010.02.007

[41] Branka, R. (2019) Creative Accounting: Motives, Techniques and Possibilities of Prevention. Ecoview and God, xxxI, BR, 193-199.

[42] Balaciu, D., Bogdan, V. and Vladu, A.B. (2009) A Brief Review of Creative Accounting Literature and Its Consequences in Practice. Annales Universitatis Apulensis Series Oeconomica, 1, 175-187.

[43] Jensen, M.C. and Mickling, W.H. (1976) Theory of the Firm: Managerial Behaviour, Agency and Ownership Structure. Journal of Financial Economics, 3, 305-360. https://doi.org/10.1016/0304-405X(76)90026-X

[44] Vladu, A.B. and Matiş, D. (2010) Corporate Governance and Creative Accounting: Two Concepts Strongly Connected? Some Interesting Insights Highlighted by Constructing the Internal History of Literature. Annales Universitatis Apulensis Series Oeconomica, 12, 332-346.

[45] Ebrahim, M.A., Abdullah, K.A. and Faudziah, H.B. (2014) The Effect of the Internal Audit and Firm Performance: A Proposed Research Framework. International Review of Management and Marketing, 4, 234-241.

[46] Ahmed, Y.A.I. (2017) Impact of Creative Accounting Techniques on the Reliability of Financial Reporting with Particular Reference to Saudi Auditors and Academics. International Journal of Economics and Financial Issues, 7, 283-291.

[47] Zuraidah, M., Chong, V.K. and Johari, R.J. (2017) Effect of Auditors Ethical Orientation and Self-Interest Independence Threat on the Mediating Role of Moral Intensity Ethical Decision-Making Process. International Journal of Auditing, 21, 38-58. https://doi.org/10.1111/ijau.12080

[48] Karim, A.M. (2016) Solution of Adapting Creative Accounting Practices: An in-Depth Perception Gap Analysis among Accountants and Auditors of Listed Companies. Australian Academy of Accounting and Finance Review, 2, 166-188. https://doi.org/10.16962/EAPJFRM/issn.2349-2317/2015/V6I4-01

[49] Lau, K.C. and Ooi, K.W. (2016) A Case Study on Fraudulent Financial Reporting: Evidence from Malaysia. Accounting Research Journal, 2, 4-19. https://doi.org/10.1108/ARJ-11-2013-0084

[50] Osazevbaru, H.O. (2012) Creative Accounting and Firms Market Value in Nigeria. Kuwait Chapter of Arabian Journal of Business and Management Review, 2, 38-50.

[51] Idris, A.A. (2012) Nature, Techniques and Prevention of Creative Accounting: Empirical Evidence from Nigeria, e-Canadian Journal of Accounting and Finance, 1, 26-31.

[52] Sanusi, B. and Izedonmi, P.F. (2014) Nigerian Commercial Banks and Creative Accounting Practices. Journal of Mathematical Finance, 4, 18-25. https://doi.org/10.4236/jmf.2014.42007

[53] Patnaik, P. (2014) Capitalism, Inequality, and Globalization: Thomas Pikettys Capital in the Twenty-First Century. International Journal of Political Economy, 43, 
55-69. https://doi.org/10.1080/08911916.2014.1001704

[54] Tassadaq, F. and Malik, Q.A. (2015) Creative Accounting and Financial Reporting: Model Development and Empirical Testing. International Journal of Economics and Financial Issues, 5, 544-551. 